\title{
THE DETERMINATION OF COUMARINS IN EXTRACTS FROM PLANTS OF THE GENUS PHILADELPHUS L.
}

\author{
Val'ko, V. - Černochová, S. - Grančai, D. \\ ${ }^{1}$ Department of Pharmacognosy and Botany, Faculty of Pharmacy, Comenius \\ University, Bratislava, Slovak Republic
}

Species of the genus Philadelphus L. (mock orange, Hydrangeaceae) are popular ornamental shrubs cultivated in Eastern Asia, Northern America, South-eastern Europe and the Caucasus. Mock orange was used to make soap, bows, arrows and cradles in the past. Aqueous extracts of Philadelphus coronarius L. flowers are used in traditional medicine and in homeopathy. Some members of the genus Philadelphus L. are known for their cytotoxic, antibacterial and immunomodulatory effects.

This study deals with quantitative determination of coumarins in different extracts (methanol, butanol, water) of leaves of Philadelphus coronarius L., Philadelphus magdalenae Rehd., Philadelphus pekinensis Rupr., Philadelphus schrenkii Rupr., Philadelphus subcanus Koehne, Philadelphus tenuifolius Rupr. et Maxim. and Philadelphus zeyheri Schrad. The content of coumarins was determined as umbelliferone using spectrophotometry.

The highest content of coumarins was recorded in methanol extract of species Philadelphus schrenkii Rupr., and butanol and water extract of Philadelphus subcanus Koehne. The results indicate higher content of coumarins in butanol and water extract compared to methanol extract.

The results obtained provide the basis for isolation and identification of biologically active substances from these extracts.

Keywords: coumarins - quantitative determination - Philadelphus $\mathrm{L}$.

\section{INTRODUCTION}

Plants play an important role as a source of effective anti-cancer agents. Currently over $60 \%$ of anti-cancer agents are derived in one way or another from natural sources, including plants, marine organisms and microorganisms [1].

Some members of the genus Philadelphus L. (Hydrangeaceae) are known for their cytotoxic, antiproliferative, apoptotic, antibacterial, antioxidant, scavenger and immunomodulatory effects. Aqueous extract from the flowers of $P$. coronarius L. is 
used in traditional medicine for the treatment of some gynaecological diseases and in homeopathy [2-9].

Coumarins (umbelliferone, scopoline), stigmasteryl-3- $\beta$-D-glucoside, uvaol, $3-\beta$-28dihydroxyoleanane-11(12),13(18)-diene and flavonoids (apigenine-7-O-glucoside, luteoline-7- $O$-glucoside, kaempferol-3- $O$-rutinoside, kvercetine-3- $O$-rutinoside) were isolated from leaves of $P$. coronarius L. Taraxerol, $\alpha$ - and $\beta$-amyrin, ursolic and oleanolic acid were reported in extract from branches of $P$. coronarius L. [9-13].

Stigmasteryl-3- $\beta$-D-glucoside, taraxerol, umbelliferone and aesculin were isolated from leaves of $P$. tenuifolius Rupr. et Maxim. [9].

Coumarins (1,2-benzopyrones) are ubiquitously found in higher plants where they originate from the phenylpropanoid pathway. They contribute essentially to the persistence of plants being involved in processes such as defence against phytopathogens, response to abiotic stresses, regulation of oxidative stress and probably hormonal regulation [14].

Some natural coumarins have been used as human therapeutics, while 4hydroxycoumarins are prominent examples of microbial modification which gave rise to the first generation molecules developed along with aspirin and heparin as anticoagulants. Other applications appear possible in the course of new developments in various therapeutic fields, like symptomatic treatment of multiple sclerosis, photochemotherapy of $\mathrm{T}$ cell lymphoma, chemotherapy of multidrug resistant tumours, organ transplants or treatment of smokers for nicotine addiction [14]. It has been found that coumarin and its derivatives also show a wide range of bioactivities such as anticoagulant, oestrogenic, dermal photosensitizing, vasodilator, molluscicidal, anthelmintic, sedative, hypnotic, analgesic, hypothermic, antimicrobial, antiinflammatory, antifungal and antiulcer [15].

This paper describes quantitative determination of coumarins in different extracts (methanol, butanol, water) of leaves of plants of the genus Philadelphus L.

\section{MATERIAL AND METHODS}

Leaves were collected at Arboretum Mlyňany, Institute of Dendrobiology, Slovak Academy of Science, in September 2005. All samples were identified by Ing. Hot'ka and voucher specimens are deposited there. Plant material was dried at room temperature. Light petrol, chloroform and methanol extracts from each part (100 g of powdered leaves) were prepared in Soxhlet apparatus until the extracts became colourless. After methanol extraction the rest of the plant material was dried and extracted with hot water $(3 \times 500 \mathrm{ml})$. The butanol fraction was prepared with subsequent re-extraction of the water extract with butan-1-ol $(3 \times 200 \mathrm{ml})$. All freshly prepared extracts were evaporated in vacuo to full dryness at temperatures not exceeding $40^{\circ} \mathrm{C}$. The water layer after the liquid-liquid extraction with butan-1-ol was evaporated to full dryness as well.

The dry material was stored at room temperature before further analyses. For the amounts of extracts from the selected plants obtained using different solvents, see Table 1. 
Table 1. Weight of obtained extracts

\begin{tabular}{|l|c|c|c|c|c|}
\cline { 2 - 6 } \multicolumn{1}{c|}{} & Light petrol & Chloroform & Methanol & Butanol & Water \\
\hline P. coronarius & 2.95 & 33.07 & 26.67 & 0.55 & 6.38 \\
\hline $\boldsymbol{P}$. magdalenae & 3.53 & 2.52 & 32.56 & 1.37 & 8.42 \\
\hline $\boldsymbol{P}$. pekinensis & 4.11 & 18.15 & 29.10 & 2.23 & 5.85 \\
\hline $\boldsymbol{P}$. schrenkii & 2.47 & 2.99 & 35.97 & 1.83 & 7.19 \\
\hline $\boldsymbol{P}$. subcanus & 3.84 & 1.95 & 31.55 & 0.38 & 8.23 \\
\hline $\boldsymbol{P}$. tenuifolius & 2.44 & 36.78 & 30.86 & 1.15 & 5.09 \\
\hline P. zeyheri & 2.52 & 2.32 & 35.50 & 0.44 & 7.97 \\
\hline
\end{tabular}

Content of coumarins was determined by using a spectrophotometric method with ammonium persulphate at $\lambda=495 \mathrm{~nm}$. The percentage content of coumarins was calculated and expressed as umbelliferone [16].

All analyses were done in triplicate. The percentage of coumarins was calculated with reference to the drug dried at $105^{\circ} \mathrm{C}$.

\section{RESULTS AND DISCUSSION}

The aim of this study was to compare the contents of coumarins in different extracts of seven species of the genus Philadelphus L. The quantification of coumarins was carried out using spectrophotometry and expressed as umbelliferone.

The results are shown in Figure 1.

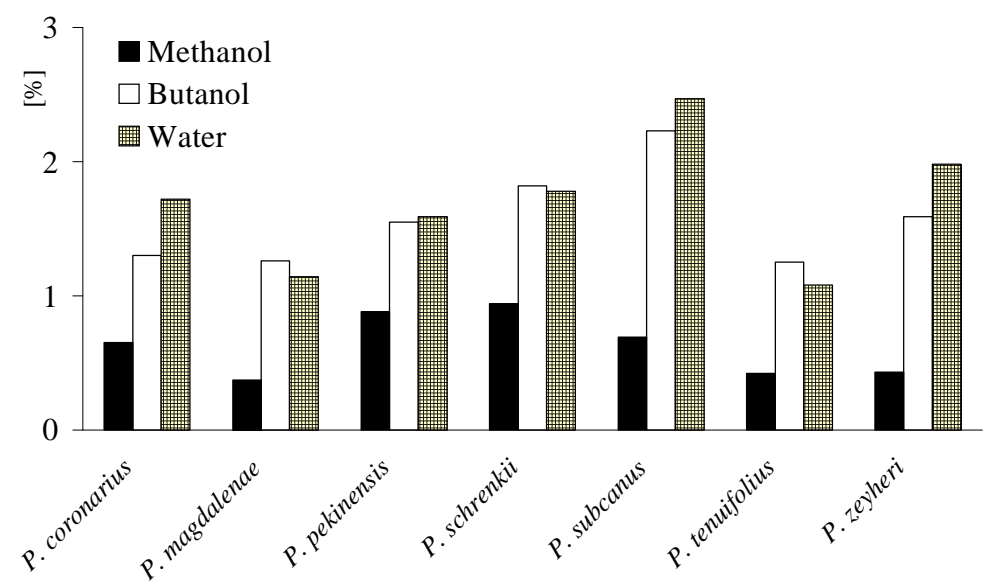

Figure 1. The percentage content of coumarins expressed as umbelliferone in 3 different extracts of different Philadelphus species leaves 
The highest content of coumarins amongst methanol extracts was recorded in Philadelphus schrenkii Rupr. (0.94\%), the lowest in species Philadelphus magdalenae Rehd. (0.37\%).

The highest content of coumarins amongst butanol extracts was measured in extract of Philadelphus subcanus Koehne (2.23\%), the lowest in Philadelphus tenuifolius Rupr. et Maxim. (1.26\%) and Philadelphus magdalenae Rehd. (1.25\%).

The highest content of coumarins amongst water extracts was determined in Philadelphus subcanus Koehne (2.47\%), the lowest in species Philadelphus tenuifolius Rupr. et Maxim. (1.08\%).

The results indicate higher content of coumarins in butanol and water extracts (1.25$2.23 \%$ resp. $1.08-2.47 \%$ ) compared to methanol ones $(0.37-0.94 \%)$.

In our previous study we found the highest content of coumarins in light petrol leaf extract of species Philadelphus pekinensis Rupr. and chloroform extract of Philadelphus magdalenae Rehd. [17].

The variation of coumarin content in the different species of the genus Philadelphus L. may be attributed to the geographical source, cultivation and age of the plants [18].

Based on these results of coumarin quantification we assume that the complex of coumarins in the studied plants of the genus Philadelphus L. is constituted predominantly by components with marked polarity, e.g. complex coumarin glycosides or polyhydroxy substituted compounds.

The results obtained provide the basis for isolation and identification of biologically active coumarins from these extracts.

\section{CONCLUSION}

This study deals with quantitative determination of coumarins in methanol, butanol and water extracts of leaves of seven species of Philadelphus plant. The content of coumarins was determined as umbelliferone using spectrophotometry. The highest content of coumarins amongst methanol extracts was recorded in Philadelphus schrenkii Rupr., the lowest one in species Philadelphus magdalenae Rehd. The highest content of coumarins amongst butanol extracts was measured in extract of Philadelphus subcanus Koehne, the lowest one in Philadelphus tenuifolius Rupr. et Maxim. and Philadelphus magdalenae Rehd. The highest content of coumarins amongst water extracts was determined in Philadelphus subcanus Koehne, the lowest one in species Philadelphus tenuifolius Rupr. et Maxim. The results indicate higher content of coumarins in butanol and water extracts compared to methanol ones.

Acknowledgement: This manuscript was written on the occasion of personal anniversary of professor Ing. Jozef Tomko, DrSc. and associated professor Dr. PhMr. Jaroslav Kresánek, CSc. This work was supported by the grant VEGA 1/0059/11. 


\section{REFERENCES}

1. NEWMAN, D.J. - CRAGG, G.M. - SNADER, K.M.: Natural products as sources of new drugs over the period 1981 - 2002. J. Nat. Prod. 66, 2003, p. 1022-1037.

2. DÁNOS, B.: Farmakobotanika - kemotaxonómia. Argumentum, Budapest, 1997, p. 262. (in Hungary)

3. HILLER, K. - MELZIG, M.F.: Lexikon der Arzneipflanzen und Drogen. 2. Band (L-Z). Spektrum Akademischer Verlag, Heidelberg, 2000, p. 148, 160.

4. CZIGLE, SZ. - MUCAJI, P. - VALKO, V. - GRANČAI, D.: Studies of the constituents of the genus Philadelphus L. Acta Facult. Pharm. Univ. Comenianae 52, 2005, p. 22-30.

5. JANTOVÁ, S. - NAGY, M. - RUŽEKOVÁ, L. - GRANČAI, D.: Antibacterial activity of plant extracts from the families Fabaceae, Oleaceae, Philadelphaceae, Rosaceae and Staphyleaceae. Phytother. Res. 14, 2000, p. 601-603.

6. KLEČÁKOVÁ, J. - CHOBOT, V. - JAHODÁŘ, L. - LAAKSO, L. - VÍCHOVÁ, P.: Antiradical activity of petals of Philadelphus coronarius L. Centr. Eur. J. Publ. Health 12, 2004, p. S39-S40.

7. VALKO, V. - PRAVDOVÁ, E. - NAGY, M. - GRANČAI, D. - FICKOVÁ, M.: Antiproliferative activity of plant extracts from genus Philadelphus L. Acta Facult. Pharm. Univ. Comenianae 54, 2007, p. 209-213.

8. VALKO, V. - PRAVDOVÁ, E. - NAGY, M. - GRANČAI, D. - FICKOVÁ, M.: Cytotoxicity of plant extracts from genus Philadelphus L. Chem. listy 101, 2007, p. S292-S293.

9. VALKO, V.: Secondary metabolites of plants of the genus Philadelphus L. and study of their biological activities. PhD. Thesis, Faculty of Pharmacy CU, Bratislava, 2009, 177 p. (in Slovak)

10. MUČAJI, P. - GRANČAI, D. - NAGY, M - CZIGLEOVÁ, S. - UBIK K.: Constituents of the twigs Philadelphus coronarius L. Farm. obzor 70, 2001, p. 311-314. (in Slovak)

11. MUČAJI, P. - GRANČAI, D. - NAGY, M. - CZIGLEOVÁ, S. - UBIK, K. - BUDĚŠÍNSKÝ, M.: Nonpolar components of the leaves of Philadelphus coronarius L. Čes. a Slov. Farm. 50, 2001, p. 274-276. (in Slovak)

12. GRANČAI, D. - VALKO, V. - ŠVAJDLENKA, E.: Constituents of Philadelphus coronarius L. Čes. a Slov. Farm. 59, 2010, p. 219-221. (in Slovak)

13. VALKO, V. - GRANČAI, D.: Flavonoid glycosides in Philadelphus coronarius L. Farm. obzor 74, 2005, p. 150-152. (in Slovak)

14. BOURGAUD, F. -HEHN, A. - LARBAT, R. - DOERPER, S. - GONTIER, E. - KELLNER, S. - MATERN, U.: Biosynthesis of coumarins in plants: a major pathway still to be unravelled for cytochrome P450 enzymes. Phytochem. Rev. 5, 2006, p. 293-308.

15. TOYAMA, D.O. - MARANGONI, S. - DIZ-FILHO, E.B.S. - OLIVEIRA, S.C.B. - TOYAMA, M.H.: Effect of umbelliferone (7-hydroxycoumarin, 7-HOC) on the enzymatic, edematogenic and necrotic activities of secretory phospholipase A2 (sPLA2) isolated from Crotalus durissus collilineatus venom. Toxicon 53, 2009, p. 417-426.

16. KAKÁČ, B. - VEJDĚLEK, Z.J. - HACHOVÁ, E.: Handbuch der Kolorimetrie. Veb Gustav Fischer Verlag, Jena, 1962, p. 626-627.

17. VALKO, V. - ČERNOCHOVÁ, S. - GRANČAI, D.: The determination of coumarins in extracts from plants of the genus Philadelphus L. and their antioxidative activity. $14^{\text {th }}$ Professional Workshop: "The Actual challenges in the medicinal and aromatic plants cultivation". Book of abstracts. Mendel university in Brno, 2008, p. 119-123. (in Slovak) 
18. CHEN, D. - WANG, J. - JIANG, Y. - ZHOU, T. - FAN, G. - WU, Y.: Separation and determination of coumarins in Fructus cnidii extracts by pressurized capillary electrochromatography using a packed column with a monolithic outlet frit. J. Pharm. Biomed. Anal. 50, 2009, p. 695-702.

PharmDr. Vojtech Val'ko, PhD.

Faculty of Pharmacy

Comenius University

Odbojárov 10

83232 Bratislava

Slovak Republic

valko@fpharm.uniba.sk

\title{
STANOVENIE KUMARÍNOV V EXTRAKTOCH RASTLÍN RODU PHILADELPHUS L.
}

\author{
Val'ko, V. - Černochová, S. - Grančai, D.
}

Katedra farmakognózie a botaniky, Farmaceutická fakulta, Univerzita Komenského, Bratislava

Druhy rodu Philadelphus L. (Hydrangeaceae) sú oblúbené okrasné kry pestované hlavne vo východnej Ázii, severnej Amerike, juhovýchodnej Európe a na Kaukaze.

Pajazmín sa v minulosti využíval na výrobu mydla, lukov, šípov a kolísok. Vodný extrakt kvetov Philadelphus coronarius L. sa používal v ludovej medicíne a v homeopatii. Niektoré druhy rodu Philadelphus L. sú známe pre svoju cytotoxickú, antibakteriálnu a imunomodulačnú aktivitu.

Táto práca sa zaoberá stanovením obsahu kumarínov v extraktoch (metanolový, butanolový, vodný) z listov druhov Philadelphus coronarius L., Philadelphus magdalenae Rehd., Philadelphus pekinensis Rupr., Philadelphus schrenkii Rupr., Philadelphus subcanus Koehne, Philadelphus tenuifolius Rupr. et Maxim. a Philadelphus zeyheri Schrad. Obsah kumarínov bol stanovený spektrofotometrickou metódou ako umbeliferón.

Najvyšší obsah kumarínov bol zistený v metanolovom extrakte druhu Philadelphus schrenkii Rupr. a v butanolovom a vodnom extrakte druhu Philadelphus subcanus Koehne. Výsledky naznačujú vyšší obsah kumarínov v butanolovom a vodnom extrakte v porovnaní s metanolovým.

Závery tejto práce sú základom pre izoláciu a identifikáciu biologicky aktívnych zložiek týchto extraktov.

Acta Facult. Pharm. Univ. Comenianae 58, 2011, p. 87 - 92. 